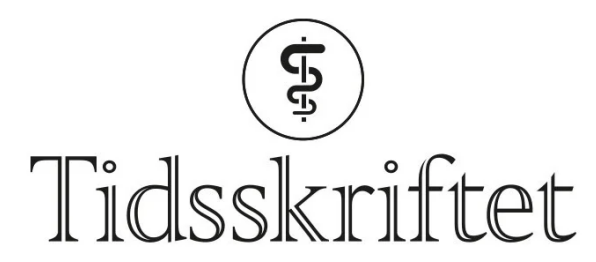

DEN NORSKE LEGEFORENING

\title{
Væskedosering ved colonkirurgi
}

NYHETER

\section{ERLEND HEM}

Email: erlend.hem@medisin.uio.no

Tidsskriftet

\section{Ulik mengde væsketilførsel under colonkirurgi ga samme komplikasjonsrate postoperativt.}

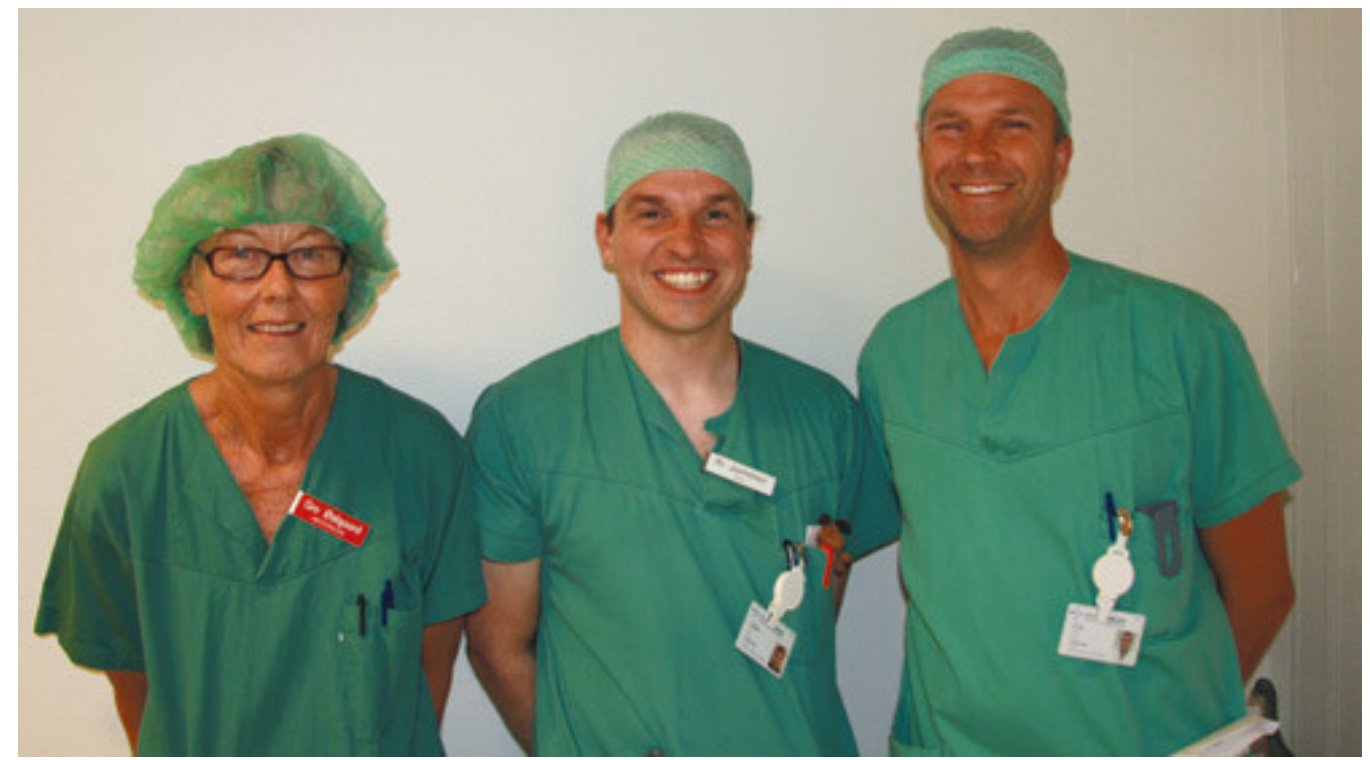

Gro Østgaard, Ib Jammer og Atle Ulvik. Foto Marit Bekkevold

Et av målene under anestesi er å opprettholde hjerteminuttvolum og tilstrekkelig oksygentilførsel til kroppens organer. For å kompensere væskeskift og væsketap under operasjonen gis intravenøs væske. Tilførselen styres dels etter antatt væskebehov, dels etter blodtrykk og urinproduksjon. Elektrolyttholdige væsker fordeles i hele

ekstracellulærvæsken, og forsøk på fylling av blodbanen må nødvendigvis medføre salt- og væskeoverskudd i kroppen. Overskuddsvæske kan gi ødemer og postoperative komplikasjoner. Hva som er den optimale mengde intravenøs væske til kirurgiske pasienter, er fortsatt en aktuell problemstilling.

Sentralvenøs oksygenmetning gir et indirekte mål på hjertets minuttvolum, oksygentilførsel og intravaskulær fylningsgrad, og har vært brukt til å styre væskebehandling hos ulike pasientgrupper. Sentralvenøs oksygenmetning kan måles ved hjelp av en blodprøve fra et sentralvenekateter med spissen i vena cava superior. 
- Vi har gjort en studie der hensikten var å finne ut om målrettet væsketerapi ved hjelp av sentralvenøs metning kunne redusere postoperativ morbiditet hos gastrokirurgiske pasienter, sier førsteforfatter Ib Jammer ved Haukeland universitetssykehus (프). I løpet av 2 år ble 241 pasienter som skulle gjennomgå elektiv, åpen colonkirurgi randomisert i to grupper. Studiegruppen fikk målrettet væsketerapi styrt etter sentralvenøs metning, mens kontrollgruppen fikk tradisjonell væskebehandling. Studiegruppen og kontrollgruppen fikk i gjennomsnitt henholdsvis 3,8 og 6,5 liter væske fra operasjonsstart frem til første postoperative dag. Selv om forskjellen i væsketilførselen var betydelig, var det ingen forskjell i andelen pasienter som fikk komplikasjoner innen 30 dager ( 42 \% i begge grupper).

- Studien er hittil den største der man har sett på sammenhengen mellom perioperativ væsketilførsel og postoperativt utfall. Til tross for at vi ikke kunne vise noen forskjell i komplikasjonsraten, tror vi fremdeles at det er viktig verken å overhydrere eller å underhydrere pasientene, uansett hvordan væsketilførselen styres og hvilke pasientgrupper man behandler, mener Jammer.

- De fleste av våre pasienter var hjerte- og lungefriske. Dette kan kanskje forklare hvorfor vi ikke fant noen forskjell i postoperativ morbiditet. Svært syke pasienter som opereres akutt, har en høyere komplikasjonsrate og kan kanskje profittere mer på målrettet væsketerapi. Dette ønsker vi å studere nærmere i en ny studie, sier Jammer.

\section{Klinisk anestesiforskning}

Artikkelen er skrevet av fem klinikere: Ib Jammer, Atle Ulvik, Christian Erichsen, Olav Lødemel og Gro Østgaard. Jammer, Ulvik og Østgaard er anestesileger ved Haukeland universitetssykehus, Erichsen er gastrokirurg samme sted og Lødemel er anestesilege ved Voss sykehus. Artikkelen har vakt oppsikt i utenlandske fagmiljøer, og et abstrakt ble nylig valgt ut som ett av de seks beste blant rundt 1 ooo konkurrerende abstrakter på den europeiske anestesilegekongressen Euroanaesthesia i regi av European Society of Anaesthesiology (ESA). 


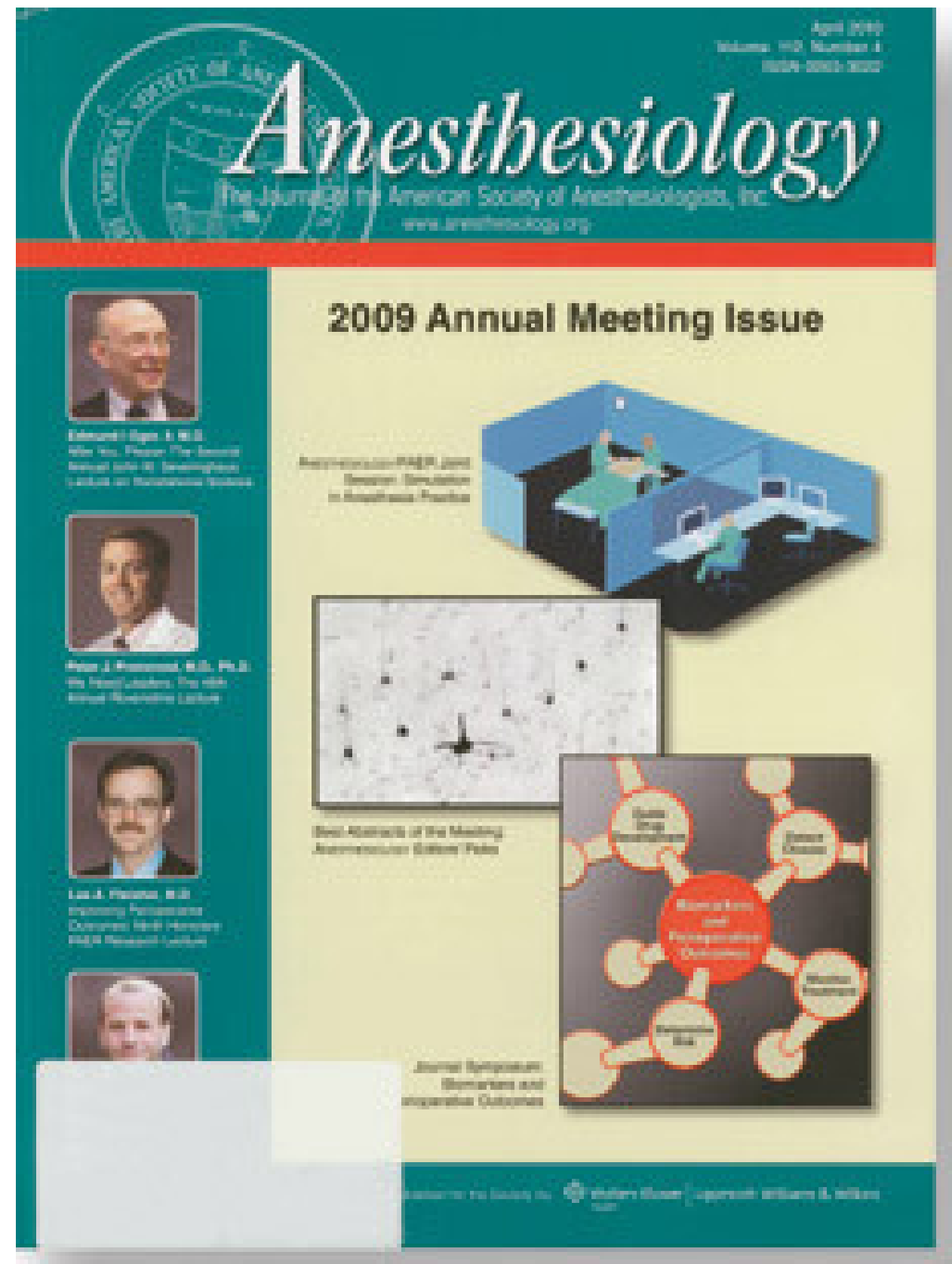

Artikkelen ble e-publisert 29.9. 2010 i Anesthesiology, som er et av de høyest rangert tidsskriftene innen anestesiologi

\section{Ordforklaringer}

Sentralvenekateter (SVK): Et kateter som legges inn i en sentral vene blant annet for å tilføre karirriterende medikamenter eller væske. Med sentral vene menes vanligvis vena cava superior, men også den nedre delen av v. cava og høyre atrium anses som en del av det sentrale venesystemet. Vanligvis punkteres vena subclavia eller vena jugularis interna. For at kateteret skal rekke inn i det sentrale venesystemet må den være relativ lang, fra $15 \mathrm{~cm}$ og oppover.

Målrettet væsketerapi: Spesiell form for væskebehandling. Pasientens hjerteminuttvolum måles direkte eller indirekte, og væske gis inntil minuttvolumet er optimalisert. 
1. Jammer I, Ulvik A, Erichsen C et al. Does central venous oxygen saturation-directed fluid therapy affect postoperative morbidity after colorectal surgery? A randomized assessor-blinded controlled trial. Anesthesiology 2010, doi:10.1097/ALN.obo13e3181f79337.

Publisert: 18. november 2010. Tidsskr Nor Legeforen. DOI: 10.4045/tidsskr.10.1093

(C) Tidsskrift for Den norske legeforening 2023. Lastet ned fra tidsskriftet.no 26. april 2023. 